\begin{tabular}{l|l|l} 
Volume. 2 \\
Islam Berbasis Sains & $\begin{array}{l}\text { Nomor.1 } \\
\text { Tahun.2017 }\end{array}$
\end{tabular}

\title{
Konsep Authentic Happiness pada Remaja dalam Perspektif Teori Myers
}

\author{
Ika Rusdiana \\ Dosen Institut Agama Islam Negeri Ponorogo \\ rosdyana.ika@gmail.com
}

\begin{abstract}
Abstrak
Fase remaja memiliki keunikan dalam menggambarkan diri mereka sendiri. Gambaran-gambaran remaja tentang dirinya sendiri kerap menimbulkan kerumitan dan sensitifitas emosional dalam hidup mereka, perluasan minat mengenai potret diri dan pencarian identitas selama masa remaja menjadikan remaja sebagai individu yang rawan mengalami konflik personal, interpersonal, dan sosial. Tulisan ini mencoba untuk menjelaskan bagaimana konsep authentic happiness remaja ditinjau dari perspektif teori Myers. konsep authentic happiness remaja diukur berdasarkan empat indikator kebahagiaan menurut Myers yaitu: 1) mampu menghargai diri sendiri sepenuhnya, 2) sikap optimis, 3) sikap terbuka dan kemampuan bersosialisasi, dan 4)kemampuan mengontrol dan mengendalikan diri sendiri sepenuhnya. Subyek penelitian ini adalah mahasiswa IAIN Ponorogo dengan rentang usia antara 17-21 tahun. Hasil penelitian menunjukkan bahwa 11\% (4 orang) remaja telah memiliki konsep authentic happiness positif (tinggi) sesuai indikator kebahagiaan Myers. 30\% (11 orang) remaja telah memiliki konsep authentic happiness tingkat sedang, sementara 59\% remaja memiliki konsep authentic happiness negatif. Dengan prosentase tersebut, remaja masih sangat rentan terhadap ancaman permasalahan-permasalahan, baik personal, interpersonal, dan sosial.
\end{abstract}

Kata Kunci: authentic happiness, remaja

\section{Abstract}

The teenage phase is unique in describing themselves. Teenage images of themselves often create emotional complexity and sensitivity in their lives, an expansion of interest in selfportrait and identity search during adolescence makes adolescents vulnerable to personal, interpersonal, and social conflict. This paper tries to explain how the concept of adolescent authentic happiness is viewed from the perspective of Myers theory. The concept of adolescent authentic happiness is measured by four indicators of happiness according to Myers: 1) fully self-esteem, 2) optimism, 3) open attitude and social skills, and 4) full control and self-control. The subjects of this study were IAIN Ponorogo students with age range between 17-21 years. The results showed that 11\% (4 people) adolescents have a concept of positive authentic happiness (high) according to Myers' happiness indicator. 30\% (11 people) of adolescents have a medium-level authentic happiness concept, while 59\% of adolescents have a negative 
authentic happiness concept. With that percentage, adolescents are still very vulnerable to the threat of problems, both personal, interpersonal, and social

Keywords : authentic happiness, teenager

\section{A. PENDAHULUAN}

Kebahagian merupakan salah satu istilah yang sulit didefinisikan, lebihlebih ditemukan padanan fisiknya. Apa yang dipahami seseorang mengenai kebahagian kerap kali berbeda terkait dengan perbedaan keadaan diri, kebutuhan, atau perkembangannya. Nasib kebahagian hampir sama seperti kebenaran, yang selalu nisbi dan relatif. Jika kita berpikir kebahagian bahwa kebahagiaan berada pada materi, mungkin itu benar. Tapi, ketika kantong sudah terisi, akankah itu menjamin kebahagian? Banyak orang yang harus membeli kesenangan, termasuk yang sangat merusak, karena merasa tidak bahagia dengan dirinya atau keadaannya. Ini petunjuk bahwa uang tidak selamanya identik dengan kebahagian.

Dalam sebuah review yang ditulis oleh Darrin M. McMahoon's book, kebahagian adalah state of mind (jiwa) yang menjadi sebab sekaligus menjadi akibatnya, meski dibutuhkan faktor eksternal yang mendukungnya. Untuk menjadi orang yang bahagia, kita pertama kali harus menciptakan pikiran yang membahagiakan (positive mind), menemukan alasan untuk bersyukur sebanyak mungkin atau menciptakan makna-makan positif sebanyak mungkin. Jika kita berhasil mendatangkan faktor eksternal yang mendukung untuk merealisasikan alasan dan makna itu, maka state of mind kita juga akan bahagia (lahir-batin).

Dalam a short history of happiness disebutkan beberapa makna kebahagiaan, diantaranya happiness=luck (homeric era), happiness=virtue (classical era), happiness=heaven (medieval era), happiness=pleasure (Enlightenment era), and happiness $=a$ warm puppy (contemporary era). ${ }^{1}$

Pada dasarnya, kebahagiaan memang memiliki banyak makna, akan tetapi pusat studi ilmiah menekankan pada dua makna. Pertama, dalam literatur filsafat kebahagiaan terkenal sebagai sinonim dari well-being, kedua, kebahagiaan hanya mencakup makna psikologis yang meliputi kondisi jiwa seseorang/individu (state of mind).

L.W. Sumner memandang authentic happiness sebagai ralat atas kesulitankesulitan yang dihadapi teori hedonistik dan teori keinginan yang menekankan pada pengalaman subjektif dan kekuasaan pribadi. Ia mengidentifikasi weel being dengan authentical happiness. Kebahagiaan dapat diartikan sebagai sebuah subjective well being, karena dalam authentic happiness mencakup kepuasan hidup secara global dan afek-afek positif,

\footnotetext{
${ }^{1}$ Pelin Kesiber and ED Diener, "In Pursuit Of Happiness: Empirical Answer to Philosophical Questions," Perspectives on Psychological Science, Vol. 2 Number 3 (n.d.): 117.
} 
hal inilah yang oleh Sumner disebut sebagai akun kepuasan hidup. ${ }^{2}$

Beberapa data tentang happiness muncul dari survey sosial, beberapa pertanyaan yang diajukan kepada responden dirangkum dalam satu pertanyaan inti "seberapa bahagiakah kamu?" dan "seberapa puaskah kamu dengan hidupmu saat ini?". Kebahagiaan merupakan sebuah faktor pengalaman, akan tetapi setidaknya terdapat tiga faktor utama dalam kebahagiaan itu sendiri, yaitu kepuasan hidup, afek positif, dan afek negatif. ${ }^{3}$

Kebahagiaan merupakan tujuan yang ingin dicapai dalam kehidupan semua orang. Berbagai cara dan usaha dilakukan manusia untuk memperoleh kebahagiaan hidup. Namun tidak jarang usaha yang tengah dilakukan manusia untuk mencapai kebahagiaan justru berujung pada situasi yang menyulitkan, dilematis, dan menimbulkan ketidakberdayaan.

Selama rentang kehidupan manusia, yang dimulai dari sejak dilahirkan sampai meninggal dunia, ada beberapa fase/tahapan perkembangan yang harus dilalui, mulai dari masa prenatal, bayi, anak-anak, remaja, dewasa, dan lansia. Masing-masing fase perkembangan sangatlah penting untuk dikaji dan dipahami secara komprehensif, namun dari semua fase perkembangan tersebut, terdapat satu fase yang menarik, unik dan menjadi perhatian untuk dikaji secara khusus yaitu fase remaja.

\footnotetext{
2 Ibid.

${ }^{3}$ Micheal Argyle, The Psychology of Happiness, Second Edition, New York: Routledge (New York: Routledge, Taylor and Francis Group, 2001), 12.
}

Mengapa remaja?, tentu ini menjadi pertanyaaan pembaca. Sebagai fase peralihan dari fase anak-anak menuju fase dewasa, fase remaja memiliki keunikan dalam menggambarkan diri mereka sendiri. Gambaran-gambaran remaja tentang dirinya sendiri kerap menimbulkan kerumitan dan sensitifitas emosional dalam hidup mereka, perluasan minat mengenai potret diri dan pencarian identitas selama masa remaja menjadikan remaja sebagai individu yang rawan mengalami konflik internal dan eksternal.

Masih hangat dalam ingatan, serangkaian berita yang viral di media mengenai kenakalan remaja, mulai dari aksi klithih para pelajar yang burujung pada kekerasan dan memakan korban jiwa, penyalahgunaan narkoba, aksi mesum pelajar , dan lain sebagainya. ${ }^{4}$

Remaja dan konsep kebahagiaan, merupakan dua aspek yang cukup menarik perhatian penulis, mengingat maraknya fenomena sosial yang disinyalir merupakan dampak dari perilaku menyimpang para remaja saat ini. Fenomena yang berkembang di masyarakat kerap menggiring pola pikir remaja pada pola pikir yang negatif, pola pikir yang mengarah pada munculnya deprivasi relatif. ${ }^{5}$

Dalam American Declaration of Independence disebutkan bahwa semua manusia diciptakan dengan derajat yang sama, dan oleh Tuhan mereka, mereka

\footnotetext{
4 “Remaja, Klithih, Dan Hal-Hal Yang Belum Selesai," accessed April 16, 2017, http://regional.liputan6.com/read/2888555/remajaklithih-dan-hal-hal-yang-belum-selesai.

${ }^{5}$ Fauzan Heru Santhoso and Moh Abdul Hakim, "Deprivasi Relatif Dan Prasangka Antar Kelompok," Jurnal Psikologi, 39 No. 1 (June 2012): 121-28.
} 
diberikan hak tertentu yang tidak dapat dicabut oleh siapapun, yaitu hak untuk hidup, kebebasan dan mendapatkan kebahagiaan. ${ }^{6}$

\section{B. KAJIAN PUSTAKA}

Setiap manusia tentunya mengharapkan dan menjadikan kebahagiaan sebagai tujuan hidup mereka, baik kebahagiaan yang bersifat sementara atau kebahagiaan yang hakiki/abadi. Kadang manusia berpikir bahwa kebahagiaan akan datang bersama dengan materi yang melimpah, atau kebahagiaan akan datang bersama dengan popularitas yang bersinar, namun ternyata tidak demikian halnya. Banyak faktor yang membuat orang merasakan kebahagiaan, berdasarkan hasil polling yang dimuat dalam Time Magazine di US tentang apa yang membuat seseorang bahagia, hasil polling menunjukkan bahwa kebanyakan orang menemukan kebahagiaan dari hubungan dengan keluarga dan temantemannya. $^{7}$

Terdapat delapan sumber kebahagiaan menurut time magazine yaitu relasi dengan anak-anak (77\%), dari teman dan persahabatan (76\%), memberikan kontribusi kepada kehidupan orang lain (75\%), hubungan dengan suami/istri (73\%), kemampuan mengontrol hidup (66\%), kemampuan memanfaatkan waktu luang (64\%), hubungan dengan orang tua (63\%),

\footnotetext{
${ }^{6}$ Argyle, The Psychology of Happiness, Second Edition, New York: Routledge, 20.

7 Joel Stein, "Marriage: Is There A Hitch", Time Magazine," 9 Januari 2005, accessed April 8, 2017, ttp://content.time.com/time/magazine/article/0,917 1,1015873,00.html./.
}

religiusitas dan spiritualitas (62\%) dan hari-hari libur seperti natal dan tahun baru (50\%). ${ }^{8}$

Rusydi (2007) menyebutkan bahwa kebahagiaan merupakan sekumpulan perasaan yang dapat dirasakan berupa perasaan senang, tentram, dan memiliki kedamaian. ${ }^{9}$

Penelitian yang dilakukan oleh Uchida, dkk. Tentang konstruksi kultural kebahagiaan, menyatakan bahwa terdapat makna kebahagiaan dalam konteks kebudayaan Barat dan Timur, kebudayaan Barat bersifat individualistik sementara kebudayaan Timur bersifat kolektivistik. ${ }^{10}$ dalam konteks budaya Barat, kebahagiaan diidentikkan dengan personal achievement, sementara dalam konteks budaya Timur, kebahagiaan lebih diidentikkan dengan pencapaian hubungan interpesonal, indikator kebahagiaan dalam konteks ini adalah dengan kelekatan individu dalam hubungan sosial. ${ }^{11}$

Imam Al-Ghozali menjelaskan bahwa tujuan hidup manusia adalah untuk mencapai kebahagiaan, sedangkan tujuan akhirnya adalah tercapainya kebahagiaan puncak, yaitu bertemunya manusia dengan Allah di kehidupan akhirat kelak. ${ }^{12}$

\footnotetext{
${ }^{8}$ Ibid.

${ }^{9}$ Rusydi, Psikologi Kebahagiaan: Dikupas Melalui Pendekatan Psikologi Yang Sangat Menyentuh Hati

(Yogyakarta: Progresif Books, 2007), 10.

${ }^{10}$ Syaiful H Radeya, "Konsep Happiness Dan Pengukurannya," 1, accessed April 8, 2017, https://www.academia.edu/8107281/KONSEP_HAPPI NESS_DAN_PENGUKURANNYA.

${ }^{11}$ Ibid., 3.

12 Fahrudin, "Hakikat Dan Tujuan Hidup Manusia Menurut Al-Ghazali," accessed April 6, 2017, http://file.upi.edu/Direktori/FPIPS/M_K_D_U/195910 081988031FAHRUDIN/konsep_manusia_alghazali.pdf.
} 
Tentu masing-masing individu memiliki cara yang berbeda untuk meraih kebahagiaannya, masing-masing individu juga memiliki ukuran yang berbeda untuk kebahagiaannya. Kebahagiaan yang dimasud disini adalah kebahagiaan yang sesungguhnya, kebahagiaan yang akan mengantarkan pemiliknya kepada kepuasan hidup, kebahagiaan yang akan menjadikan pemiliknya benar-benar menemukan makna tertinggi dalam hidupnya. ${ }^{13}$

Dari teori yang dibangun oleh Martin E. Seligman, menyebutkan bahwa terdapat tiga jenis kebahagiaan yang berbeda, yaitu kehidupan yang menyenangkan (pleasures), hidup yang baik (keterlibatan) dan hidup yang bermakna. ${ }^{14}$ Dua kebahagiaan yang pertama adalah subyektif, sedangkan yang ke tiga lebih bersifat obyektif dan memiliki sesuatu yang lebih berharga dan bernilai daripada kenikmatan yang bersifat keinginan. Masih dalam Seligman (2002), dinyatakan bahwa authentic happiness mensintesis ke tiga kebahagiaan tersebut. Authentic happiness adalah full life yang memenuhi tiga kriteria kebahagiaan.

Veenhoven (2007) menyebutkan

bahwa konsep kebahagiaan adalah merupakan sinonim dari kepuasan hidup (satisfaction of life) ${ }^{15}$, sementara satisfaction of life menurut Diener (2007)

\footnotetext{
${ }^{13}$ Michael Eid and Randy J Larsen, The Science of Subjective Well-Being, New (New York: The Gulford Press, 2008), 17.

${ }^{14}$ Martin E.P Seligman, Authentic Happiness: Using The New Positive Psychology To Realize Your Potential For Lasting Fulfillment (New York: The Free Press, 2002), 10.

${ }^{15}$ Ruut Veenhoven, "Orientation to Happiness and Life Satisfaction: The Full Life versus the Empty Life," Journal of happiness studies, Vol. 14 (n.d.): 141-46.
}

merupakan bentuk nyata dari happiness atau kebahagiaan dimana kebahagiaan tersebut merupakan sesuatu yang lebih dari suatu pencapaian tujuan, dikarenakan pada faktanya kebahagiaan selalu dihubungkan dengan kondisi kesehatan yang baik, pencapaian prestasi kerja, dan lain sebagainya. ${ }^{16}$

Kata kebahagiaan sering digunakan dalam berbagai makna yang berbeda, dan untuk mengatasi beberapa kebingungan haruslah dianalisis lebih rinci hal-hal berikut:

1) Arti kata kebahagiaan. Dalam area yang lebih luas, kebahagiaan sama artinya dengan kualitas hidup atau kesejahteraan. Dalam konteks ini jelas yang dimaksud adalah kehidupan yang baik, namun secara lebih spesifik pertanyaannya adalah kehidupan baik yang seperti apa. Terdapat empat unsur dalam kualitas hidup seseorang, yaitu:

\begin{tabular}{|l|l|l|}
\hline & $\begin{array}{l}\text { Outer } \\
\text { qualities }\end{array}$ & $\begin{array}{l}\text { Inner } \\
\text { qualities }\end{array}$ \\
\hline $\begin{array}{l}\text { Life- } \\
\text { chances }\end{array}$ & $\begin{array}{l}\text { Livability of } \\
\text { environment }\end{array}$ & $\begin{array}{l}\text { Life-ability of } \\
\text { the person }\end{array}$ \\
\hline $\begin{array}{l}\text { Life- } \\
\text { results }\end{array}$ & Utility of life & Satisfaction \\
\hline
\end{tabular}

2) Definisi kebahagiaan sebagai kepuasan hidup. Hal ini membawa kita untuk memberikan makna kepuasan hidup secara tepat, beberapa pandangan menyatakan bahwa kepuasan hidup sering dihubungkan dengan proses mental seseorang.

\footnotetext{
16 Ibid.
} 
3) Konseptualisasi overall happiness dan components. Overall happiness didefinisikan sebagai sebuah tingkatan dimana individu menilai seluruh kualiatas hidupnya sebagai kebaikan yang menyeluruh/komprehensif. ${ }^{17}$ Sedangkan components didefinisikan sebagai sejumlah perasaan dan keyakinan yang muncul pada saat tertentu, misalnya, suatu saat seseorang merasa dalam kondisi sangat baik, tapi kadang kala ia juga merasa cemas.

Dari ke tiga poin di atas, kiranya dapat ditarik sebuah konsep penting bahwa yang dimaksud dengan authentic happiness adalah overall happiness, yaitu kebahagiaan secara menyeluruh yang merupakan kristalisasi nilai kualitas hidup seseorang. Beberapa indikator untuk mengidentifikasi authentic happiness diantaranya adalah: being happy, yaitu suatu kondisi kehidupan seseorang yang mampu merefleksikan nilai-nilai dalam kehidupannya dan bukan merupakan manipulasi. Diantara aspek yang tercakup dalam authentic happiness adalah life satisfaction (kepuasan hidup), kebahagiaan yang otentik menuntut/menggabungkan unsur pengalaman, pengalaman-pengalaman tersebut akan dikristalisasi menjadi satu kesatuan yang utuh.

Selain dari indikator authentic happiness di atas, setidaknya ada empat definisi yang dapat digunakan untuk menjelaskan aspek-aspek authentic happiness yaitu:

1) Affective definitions. Wessman \& Ricks (1966) menyatakan bahwa kebahagiaan

\footnotetext{
17 Ibid.
}

merupakan sebuah hasil evaluasi menyeluruh terhadap kualitas pengalaman individu. Sebagai contoh, kebahagiaan merepresentasikan sebuah gambaran yang diringkas dari perubahan hidup yang terus menerus. ${ }^{18}$

2) Cognitive definitions. Kebahagiaan juga didefinisikan sebagai fenomena kognitif dan merupakan hasil dari proses evaluasi yang dilakukan secara sadar dan sengaja. Dalam hal ini, Vein McDowel \& Newell (1987) menyebutkan bahwa kepuasan hidup sebagai "Personal assessment of one's condition compared to an external reference standard or to one's aspirations". ${ }^{19}$

3) Attitudinal definitions. Dalam konteks ini kebahagiaan digambarkan sebagai disposisi senang dan sikap positif pada hidup.

4) Mixed definitions. Dalam definisi campuran, kebahagiaan didefinisikan sebagai gabungan dari beberapa elemen seperti elemen sikap (attitude) yang tercermin dalam kepuasan hidup, elemen afeksi (affect) yang tercermin dalam perasaan baik/positif (feeling good).

Seligman (2002) menjelaskan tentang kehidupan yang utuh atau dapat diartikan merasakan kebahagiaan otentik adalah mengalami emosi positif tentang masa lalu dan masa sekarang, menghayati perasaan positif dari kenikmatan, memperoleh banyak gratifikasi dengan cara mengerahkan kekuatan pribadi, dan menggunakan kekuatan ini untuk sesuatu

\footnotetext{
${ }^{18}$ Ruut Veenhoven, Condition of Happiness (Holland: D. Reidel Publishing Company, 1984), 84. ${ }^{19}$ Ibid., 82.
} 
yang lebih besar. Aspek kebahagiaan otentik menurut Seligman (2002) yaitu: ${ }^{20}$

a. Kepuasan akan masa lalu

b. Kebahagiaan pada masa sekarang

c. Optimisme akan masa depan

\section{METODE PENELITIAN}

Pendekatan yang digunakan dalam penelitian ini adalah pendekatan kualitatif, yaitu sebuah pendekatan penelitian yang bertujuan untuk menangkap makna secara mendalam, penelitian yang temuantemuannya tidak diperoleh melalui prosedur statisktik. ${ }^{21}$ Penelitian ini dimaksudkan untuk mengungkapkan gejala secara holistic-kontekstual melalui pengumpulan data dari latar alami dengan memanfaatkan diri peneliti sebagai instrumen kunci. Penelitian kualitatif bersifat deskriptif dan cenderung menggunakan analisis dengan pendekatan induktif. Proses dan makna (perspektif subyek) lebih ditonjolkan dalam penelitian kualitatif. 22

Pada penelitian ini, teori digunakan sebagai theoretical lens atau perspektif dalam penelitian. Seorang peneliti dalam kegiatan penelitiannya, baik dinyatakan secara eksplisit atau tidak, menerapkan paradigma tertentu sehingga penelitian menjadi terarah. ${ }^{23}$

Subyek penelitian ini adalah mahasiswa IAIN Ponorogo yang berusia

\footnotetext{
${ }^{20}$ Seligman, Authentic Happiness: Using The New Positive Psychology To Realize Your Potential For Lasting Fulfillment, 17.

${ }^{21}$ Anselm Strauss and Juliet Corbin, Dasar-Dasar Penelitian Kualitatif: Tata Langkah Dan Teknik-Teknik Teoritisasi Data (Yogyakarta: Pustaka Pelajar, 2007), 5. 22 Ibid.

${ }^{23}$ John W Creswell, Research Design: Qualitative, Quantitative, and Mixed Methods Approaches (California: SAGE Publications. Inc, 2009), 63.
}

antara 17-21 tahun. Teknik sampling yang digunakan dalam penelitian ini adalah theoritic sampling (penyampelan teoretik), yaitu pengambilan sampel berdasarkan konsep-konsep yang terbukti berhubungan secara teoretik dengan teori yang sedang disusun. ${ }^{24}$ Konsep kebahagiaan diukur dengan menggunakan dua prediktor kebahagiaan, yaitu: 1) afeksi, dan 2) kepuasan hidup. Afeksi merupakan perasaan yang berhubungan dengan pengalaman emosional baik berupa perasaan yang menyenangkan maupun perasaan yang tidak menyenangkan. Sementara untuk prediktor kepuasan hidup diukur dengan melihat karakteristik-karakteristik diantaranya: 1) sikap menghargai diri sendiri, dan 2) sikap optimistis.

\section{PEMBAHASAN}

Sebagaimana dipaparkan pada penjelasan sebelumnya, bahwa konsep authentic happiness remaja diukur berdasarkan empat indikator kebahagiaan menurut Myers yaitu: 1) mampu menghargai diri sendiri sepenuhnya, 2) sikap optimis, 3) sikap terbuka dan kemampuan bersosialisasi, dan 4)kemampuan mengontrol dan mengendalikan diri sendiri sepenuhnya.

Hasil interview terhadap 36 mahasiswa dapat dirinci dalam tabel berikut:

\footnotetext{
${ }^{24}$ Strauss and Corbin, Dasar-Dasar Penelitian Kualitatif: Tata Langkah Dan Teknik-Teknik Teoritisasi Data, 196.
} 
Tabel. 1 Indikator Kebahagiaan

\begin{tabular}{|l|c|c|c|}
\hline \multicolumn{1}{|c|}{ Indikator Kebahagiaan } & Iya & Tidak & $\%$ \\
\hline $\begin{array}{l}\text { Mampu menghargai diri sendiri } \\
\text { sepenuhnya }\end{array}$ & 4 & 32 & $89 \%$ \\
\hline Sikap optimis dan kemampuan & 27 & 9 & $25 \%$ \\
\hline $\begin{array}{l}\text { Sikap terbuka dan } \\
\text { bersosialisasi }\end{array}$ & 11 & 25 & $69 \%$ \\
\hline $\begin{array}{l}\text { Kemampuan mengontrol diri sendiri sepenuhnya } \\
\text { mengendalikan diri di }\end{array}$ & & 22 & $61 \%$ \\
\hline
\end{tabular}

Dari tabel di atas dapat diketahui: pertama, kemampuan remaja dalam menghargai diri sendiri masih sangat rendah. Dalam hal ini, 89\% remaja belum memiliki perasaan yang kuat untuk menghargai dan mempercayai diri sendiri sehingga belum mampu sepenuhnya mengembangkan potensi yang mereka miliki. Ketidakmampuan remaja dalam menghargai diri sendiri kerap menggiring pada pola-pola perilaku yang kontraproduktif, kegagalan dalan menjalin hubungan yang sehat, serta kesulitan untuk melihat dan menghargai keunikan diri sendiri. Kemampuan menghargai diri sendiri merupakan sebuah bentuk integrasi identitas dan perasaan pada remaja sebagai wujud tercapainya identitas peran dalam kehidupannya. Rendahnya kemampuan remaja dalam menghargai diri sendiri merupakan salah satu indikator krisis identitas yang memicu munculnya kenakalan remaja.

Kedua, hasil penelitian menunjukkan bahwa $61 \%$ remaja memiliki sikap optimis yang ditunjukkan dengan sikap pribadi dan sosial yang dicirikan dengan keyakinan akan pentingnya usaha untuk mencapai kehidupan yang lebih baik di masa mendatang. Remaja yang dalam penelitian ini menyatakan dirinya sebagai individu yang optimis, adalah mereka yang juga menyatakan mampu untuk menghargai diri sendiri. Dengan demikian dapat disimpulkan bahwa terdapat keterkaitan antara sikap optimis dan menghargai diri sendiri dalam pembentukan konsep kebahagiaan pada remaja. Mengapa optimisme?, karena optimisme akan membawa remaja pada tujuan yang diinginkan, menumbuhkan kepercayaan diri akan kemampuan yang dimiliki, dan sanggup memprediksi bahwa dengan kemampuan yang dimiliki cita-citanya akan tercapai.

Ketiga, hasil penelitian menunjukkan, hanya $25 \%$ remaja yang memiliki sikap tertutup dan mengalami kesulitan dalam bersoasialisasi. 75\% remaja menyatakan dirinya bersikap terbuka dan mudah untuk bersosialisasi dengan lingkungannya. Sikap ini dibuktikan dengan pernyataan remaja yang selalu mengkomunikasikan permasalahan-permasalaan yang dialami individu kepada orang-orang terdekat seperti orang tua dan teman sebaya. Di samping itu, perilaku prososial remaja juga dinyatakan dengan tindakan berbagi (sharing), kerjasama (cooperation), meno- 
long (helping), kejujuran (honesty), dan dermawan (generousity).

Keempat, hasil penelitian menunjukkan bahwa $69 \%$ remaja belum dan atau tidak memiliki kontrol terhadap diri sendiri. Mereka menyatakan bahwa sebagai remaja mereka sering ikut-ikutan apa yang dilakukan oleh teman-temannya. Dengan berbagai pertimbangan, mulai dari perasaan sungkan pada teman, adanya kekhawatiran dikucilkan oleh komunitas sosial, sampai pada pertahanan eksistensi sebagai seorang remaja. Minimnya self control pada remaja merupakan hal yang lazim dan wajar terjadi pada remaja, mengingat kemampuan self control adalah life long learning yang akan muncul, tumbuh, dan berkembang sepanjang kehidupan manusia.

\section{E. KESIMPULAN}

Keempat indikator kebahagiaan yang dicetuskan oleh Myers, sikap terbuka dan kemampuan bersosialisasi merupakan indikator terbesar dalam membentuk konsep kebahagiaan remaja. Meski demikian, indikator ini menjadi tidak signifikan karena tidak sinergis dengan ketiga indikator lainnya.

Kemampuan menghargai diri sendiri merupakan faktor yang paling berpengaruh dalam membentuk konsep kebahagiaan pada remaja, apabila remaja mampu untuk lebih menghargai diri mereka sendiri dimungkinkan remaja akan mendapatkan konsep kebahagiaan yang lebih hakiki, hal ini dikarenakan kemampuan menghargai diri sendiri memiliki korelasi dengan indikator kebahagiaan yang lain, seperti sikap optimis dan keterbukaan dalam hubungan sosial.
Indikator kebahagiaan kedua yang mendominasi pembentukan konsep kebahagiaan pada remaja adalah kemampuan dalam self control. Remaja yang belum dan atau tidak memiliki kemampuan self control akan kesulitan untuk menentukan arah langkah perilakunya secara bebas, bebas dengan tetap mengedepankan tanggung jawab yang memperhatikan adanya hak dan kewajiban pada masingmasing individu.

Indikator ketiga yang mempengaruhi dalam pembentukan konsep kebahagiaan remaja adalah sikap optimis. Pada dasarnya sikap optimis yang dimiliki remaja merupakan manifestasi dari indikator pertama yaitu kemampuan menghargai diri sendiri.

Hasil penelitian menunjukkan bahwa $11 \%$ (4 orang) remaja telah memiliki konsep authentic happiness positif (tinggi) sesuai indikator kebahagiaan Myers. 30\% (11 orang) remaja telah memiliki konsep authentic happiness tingkat sedang, sementara 59\% remaja memiliki konsep authentic happiness negatif. Dengan prosentase tersebut, remaja masih sangat rentan terhadap ancaman permasalahanpermasalahan, baik personal, interpersonal, dan sosial. Sebagaimana yang dipaparkan oleh Santrock (2003), bahwa diantara alasan remaja mengkonsumsi narkoba adalah karena rasa ingin tahu, untuk meningkatkan rasa percaya diri, solidaritas, adaptasi dengan lingkungan, serta kompensasi. Dengan demikian, remaja membutuhkan arahan dan dukungan sosial untuk memunculkan kesadaran dan pemahaman diri akan adanya nilai-nilai positif, pengalaman, dan sikap yang kemudian ditetapkan sebagai tujuan 
hidup mereka. Atas dasar inilah akan muncul perubahan cara pandang, konsep, dan sikap (changing attitude) remaja dalam menghadapi berbagai permasalahan.

\section{F. DAFTAR PUSTAKA}

Argyle, Micheal. The Psychology of Happiness, Second Edition, New York: Routledge. New York: Routledge, Taylor and Francis Group, 2001.

Creswell, John W. Research Design: Qualitative, Quantitative, and Mixed Methods Approaches. California: SAGE Publications. Inc, 2009.

Eid, Michael, and Randy J Larsen. The Science Of Subjective Well-Being, New. New York: The Gulford Press, 2008.

Fahrudin. "Hakikat Dan Tujuan Hidup Manusia Menurut Al-Ghazali." Accessed April 6, 2017. http://file.upi.edu/Direktori/FPIPS/M K_D_U/195910081988031FAHRUDIN/ konsep_manusia_al-ghazali.pdf.

Kesiber, Pelin, and ED Diener. "In Pursuit Of Happiness: Empirical Answer to Philosophical Questions," Perspectives on Psychological Science, Vol. 2 Number 3 (n.d.).

Radeya, Syaiful H. "Konsep Happiness Dan Pengukurannya." Accessed April 8, 2017. https://www.academia.edu/8107281/ KONSEP_HAPPINESS_DAN_PENGUKUR ANNYA.

"Remaja, Klithih, Dan Hal-Hal Yang Belum Selesai." Accessed April 16, 2017. http://regional.liputan6.com/read/288 8555/remaja-klithih-dan-hal-hal-yangbelum-selesai.

Rusydi. Psikologi Kebahagiaan: Dikupas Melalui Pendekatan Psikologi Yang Sangat Menyentuh Hati. Yogyakarta: Progresif Books, 2007.

Santhoso, Fauzan Heru, and Moh Abdul Hakim. "Deprivasi Relatif Dan
Prasangka Antar Kelompok," Jurnal Psikologi, 39 No. 1 (June 2012).

Seligman, Martin E.P. Authentic Happiness: Using The New Positive Psychology To Realize Your Potential For Lasting Fulfillment. New York: The Free Press, 2002.

Stein, Joel. "Marriage: Is There A Hitch", Time Magazine." 9 Januari 2005. Accessed April 8, 2017. ttp://content.time.com/time/magazine /article/0,9171,1015873,00.html./.

Strauss, Anselm, and Juliet Corbin. DasarDasar Penelitian Kualitatif: Tata Langkah Dan Teknik-Teknik Teoritisasi Data. Yogyakarta: Pustaka Pelajar, 2007.

Veenhoven, Ruut. Condition of Happiness. Holland: D. Reidel Publishing Company, 1984.

-_—. "Orientation to Happiness and Life Satisfaction: The Full Life versus the Empty Life," Journal of happiness studies, Vol. 14 (n.d.). 